\title{
Giovanni Pontiero: Translations of Mário Quintana
}

John Milton

I met Giovanni Pontiero for the first and only time at a congress in Birmingham in September 1993. I was immediately impressed by his quiet politeness and friendliness. At that time we were organizing the $V$ Encontro de Tradutores, which would be held the following May in Salvador. I invited him to come. Unfortunately he couldn't make it. I asked him to contribute to the Brazilian section of Modern Poetry in Translation, No. 6, which I was preparing. He sent me unpublished poems of Cecília Meirelles, which were included. Then I heard he was very ill. He finally died in 1996.

Giovanni occupies a central position in the definition and spread of Brazilian Portuguese literature in the English speaking world. He translated a large number of Brazilian poets, which were mainly published in New Directions: Manuel Bandeira, Carlos Drummond de Andrade, Lêdo lvo, Carlos Nejar and Antônio Osório from Portugal. He published short stories by Patricia Bins, Nélida Piñon, the Portuguese authors Agustina Bessa Luís, José Cardoso Pires, and the Spanish-American Carlos Martínez Moreno. He also translated Daniel Moyano's El Trino del diablo (The Devil's Trill), Lya Luft's Exilio (The Red House, Carcanet, 1993), and Ana Miranda's Boca do Inferno (The Bay of all Saints and every Conceivable Sin, Harvill 1991; Viking 1991). But it as the translator of Clarice Lispector and José Saramago that Giovanni will be best remembered. From 1984 to 1997 he published the following works 
of Clarice: Laços de Família (Family Ties, Carcanet, 1984), A Legiấo Estrangeira (The Foreign Legion, Carcanet, 1986), A Hora de Estrela (The Hour of the Star, Paladin Grafton, 1987), Perto do Coração Selvagem (Near to the Wild Heart, Carcanet, 1990), the collection of chronicles A Descoberta do Mundo (Discovering the World, Carcanet, 1992), and A Cidade Sitiada (The Beseiged City, Carcanet, 1997).

Giovanni's translations of Saramago began in 1987 with Memorial do Convento (Baltasar and Blimunda, Harcourt Brace Jovanovich, 1987; Jonathan Cape 1980), followed by O Ano da Morte de Ricardo Reis (The Year of the Death of Ricardo Reis, Harcourt Brace Jovanovich, 1991; Harvill, 1994), O Evangelho segundo Jesus Cristo (The Gospel according to Jesus Christ, Harcourt Brace Jovanovich, 1993; Harvill, 1993), A Jangada de Pedra (The Stone Raft, Harcourt Brace Jovanovich, 1995; Harvill, 1994), Manual de Pintura e Caligrafia (Manual of Painting and Calligraphy (Carcanet, 1994), História de Cerco de Lisboa (History of the Siege of Lisbon Harvill, 1996), Ensaio sobre a Cegueira (On Blindness Harvill, 1997).

The popularity that Clarice and Sarmago have gained in recent years in the English-speaking world has, to a large extent, been through Giovanni's translations. Their fortunes have been very different. Clarice has been adopted by American and French feminism, notably by Helène Cixous, and is, perhaps, read by a narrower audience than in Portuguese. Saramago, as is well-known, was awarded the Nobel Prize for Literature in 1998. The great majority of the adjudicators would have read his work in the English translations.

How did Giovanni begin as a literary translator? In "Risks and Rewards of Literary Translation", an essay in The Translator's Dialogue: Giovanni Pontiero, a collection of Giovanni's essays, an unpublished translation of a Saramago short story and comments by Giovanni, edited by Pilar Orero and Juan C. Sager, (John Benjamins 1997), we learn how he managed to get his foot in the 
door, showering literary magazines and anthologies with translations until something was accepted. Finally, in 1972, his translation of Lispector's short story "Amor" was accepted by New Directions. The University of Texas Press asked him to translate the whole of Family Ties. Gregory Rabassa qualified his translation as "magnificent", and there was no looking back. Pontiero became highly respected both in the academic and the publishing world.

Giovanni places translation as an adjunct to creative writing, mentioning that in some countries, like Brazil, most literary translators are creative writers. "The literary translator must have the instincts and drives that go to make a good writer" (The Translator's Dialogue:21).

His priorities when selecting a book to translate were that the translation must offer a serious challenge, that the author must be significant in his or her time, and that the topic of the book should have a certain universality. He mainly translated living novelists whom he would usually get to know personally. While translating he would be in regular contact with the author. This dialogue could have considerable influence on the author as when he translated Moyano's El Trino del Diablo. Giovanni sent a list of queries to the author, who wrote back, saying that Giovanni had made him reflect on some of the inadequacies of the original text, and that he would send him a few modifications within a month. But what Moyano sent Pontiero was an almost completely rewritten original! As the first translation was almost complete, Giovanni was not going to redo the translation, and the publisher was not going to pay for another translation, so the original translation was published. The rewritten version was used, however, when the novel was reprinted later, without indicating that it had been revised.

Moyano was not the only author whom Pontiero influenced. Saramago comments: "The long lists of queries and doubts I received, always written in Pontiero's minuscule hand, in which every word seemed to be carefully traced letter by letter, were like 
doors opening to give me a deeper understanding of my own language"(Ibid: 86). The Brazilian writer Ana Miranda also received cards in Pontiero's "delicate minuscule handwriting" containing queries and doubts. "Many times I had the impression that he knew the answer but wanted to talk, maintain contact, deepen his understanding; that he wanted to participate more fully in the creation of the novel, its genesis. At other times I had the impression that his questions were intended to get to know me better, to get a wider understanding of my world." (lbid: 92) And many of the questions he made forced her to go back to study the original source texts more closely. After the publication of The Bay of All Saints and Every Conceivable Sin, she used Pontiero's notes to produce of a manual for translators of her book into other languages.

Giovanni was a methodical, devoted and stylistic translator. The fact he was a lecturer at Manchester University meant that he was able not to depend on his translators fees for a living and could uses the university library facilities for background studies. He tried to develop close relationships with the authors he translated. Clarice died shortly after he started translating her work, but he developed a close friendship with Saramago and was in frequent contact with Lya Luft and Ana Miranda when translating their novels. $\mathrm{He}$ insisted that the translator should have control over the final published translation after the negative experience of his first translation of Saramago, when, after carefully reproducing the mixture of narration and dialogue, separated only by commas, he found that the copy editors had changed this into standard dialogue with inverted commas and line division.

It gives me great pleasure to present these unpublished translations by Giovanni of Mário Quintana's poetry. The next edition of Cadernos de Literatura em Tradução will publish Giovanni's translations of Quintana's aphorisms. 


\section{POEMA}

Um poema como um gole d'água bebido no escuro.

Como um pobre animal palpitando ferido.

Como pequenina moeda de prata perdida para sempre na floresta noturna.

Um poema sem outra angústia que a sua misteriosa condição de poema.

Triste.

Solitário.

Único.

Ferido de mortal beleza

\section{THe POEM}

A poem like a drink of water gulped in the dark. Like a poor wounded animal gasping for breath. Like a tiny silver coin lost forever in a black forest.

A poem with no trauma other than its mysterious condition as a poem.

Morose.

Solitary.

Unique.

Wounded by mortal beauty.

\section{Objetos Perdidos}

Os guarda-chuvas perdidos... aonde vão parar os guarda-chuvas perdidos? $\mathrm{E}$ os botōes que se desprenderam? $\mathrm{E}$ as pastas de papéis, os estojos de pince-nez, as maletas esquecidas nas gares, as 
dentaduras postiças, os pacotes de compras, os lenços com pequenas economias, aonde vão parar todos esses objetos heteróclitos e tristes? Não sabes? Vão parar nos anéis de Saturno, são eles que formam, eternamente girando, os estranhos anéis desse planeta misterioso e amigo.

\section{LOST ОвJeCtS}

Lost umbrellas... where do lost umbrellas end up? And the buttons that come off? And those paper files, cases for pince-nez, suitcases forgotten in railway stations, false teeth, mislaid parcels, those tiny savings wrapped inside a handkerchief, where do all these objects, ridiculous and sad, end up? Don't you know? They end up in the rings of Saturn, where eternally revolving, they form the mysterious rings of that strange and friendly planet.

\section{Noturno Arabaleiro}

Os grilos... os grilos... Meu Deus, se a gente Pudesse

Puxar

Por uma

Perna

Um só

Grilo,

Se desfiariam todas las estrelas!

\section{SUbURBAN Nocturne}

Crickets... Crickets... Dear God, if we Could 
Pull

But one

Cricket

By the

Leg,

All the stars would scatter.

\section{MOMEnTO}

O mundo é frágil

E cheio de frêmitos

Como um aquário...

Sobre ele desenho

Este poema: imagem

De imagens!

\section{MOMENT}

The world is fragile

And full of ripples

Like an aquarium...

On top I design

This poem: image

Of images! 
MILTON, John. Giovanni Pontiero: Translations of Mario Quintana

\section{CITAÇÃO}

E melhor se poderia dizer dos petas o que disse dos ventos Machado de Assis: "A dispersão não lhes tira a unidade, nem a inquietude a constância".

\section{QUOTATION}

What Machado de Assis said about the winds could be more aptly said about poets: "Dispersion doesn't take away unity, nor disquiet rob them of their constancy".

\section{Os Degraus}

Não desças os degraus do sonho Para não despertar os monstros.

Não subas aos sótãos - onde

Os deuses, por trás das suas máscaras, Ocultam o próprio enigma.

Não desças, não subas, fica.

O mistério está é na tua vida!

E é um sonho louco este nosso mundo...

\section{STAIRS}

Don't go down the stairs of dreams Lest you awaken the monsters.

Don't climb into attics - where

The gods, behind their masks, 
Conceal their own enigma.

Don't go down, don't go up, stay put.

The mystery is your own existence!

And this world of ours is a crazy dream...

\section{A CONSTRUÇÃo}

Eles ergueram a Torre de Babel

Para escalar o Céu.

Mas Deus não estava lá!

Estava ali mesmo, entre eles,

Ajudando a construir a torre.

\section{The Tower of Babel}

They raised the Tower of Babel

To climb into Heaven,

But God wasn't there!

He was down there among them

Helping to build the tower.

\section{EMERGÊNCIA}

Quem faz um poema abre uma janela.

Respira, tu que estás numa cela abafada,

Esse ar que entra por ela.

Por isso é que os poemas têm ritmo

-- para que possas profundamente respirar.

Quem faz um poema salva um afogado. 
MILTON, John. Giovanni Ponfiero: Translations of Mario Quintana

\section{EMERGENCY}

When someone writes a poem they open a window.

Inhale the fresh air penetrating your stuffy cell.

That's why the poem has rhythm

-- so that you may take a deep breath.

When someone writes a poem, they save a man from suffering.

\section{TeMPo Perdido}

Havia um tempo de cadeiras na calçada. Era um tempo em que havia mais estrelas. Tempo em que as crianças brincavam sob a clarabóia da lua. E o cachorro da casa era um grande personagem. E também o relógio de parede! Ele não media o tempo simplesmente: ele meditava o tempo.

\section{IRRETRIEVABLE TIME}

Once upon a time there were chairs upon the pavements. Once upon a time there were more stars. Once upon a time children played under the skylight of the moon. And the family dog was held in esteem. As for the clock on the wall! It didn't simply measure time: it pondered time.

\section{BiLHETE}

Se tu me amas, ama-me baixinho

Não o grites de cima dos telhados

Deixa em paz os passarinhos 
Deixa em paz a mim!

Se me queres,

Enfim, tem de ser bem devagarinho, Amada,

Que a vida é breve, e o amor mais breve ainda...

\section{Billet-doux}

If you love me, love me discreetly

Don't shout it from the rooftops

Don't disturb the birds

Don't disturb me!

If you love me,

That's all right,

But take it easy, darling

For life is short, and love is shorter still...

\section{ENVELHECER}

Antes, todos os caminhos iam.

Agora todos os caminhos vêm.

A casa é acolhedora, os livros poucos,

E eu mesmo preparo o chá para os fantasmas.

\section{GrowING OLD}

Before, all roads went.

Now all roads come.

The house is welcoming, few books remain.

And I myself prepare tea for the ghosts. 


\section{CRÓNICA}

Ah, essas pequenas coisas, tão quotidianas, tão prosaicas às vezes, de que se compöe meticulosamente a tecitura de um poema... talvez a poesia não passe de um gênero de crônica: uma espécie de crônica da eternidade.

\section{Chronicle}

Ah, these trifling things, so humdrum, sometimes so prosaic, with which the texture of the poem is meticulously composed... poetry may be simply a kind of chronicle and nothing more: a chronicle of eternity.

\section{O Disfarce}

Cansado da sua beleza angélica, o Anjo vivia ensaiando caretas diante do espelho, Até que conseguiu a obra-prima do horror. Veio, assim, dar uma volta pela Terra. E Lili, a primeira meninazinha que o avistou, põe-se a gritar da porta para dentro de casa: "Mamãe! Mamãe! Vem ver como o Frankenstein está bonito hoje!"

\section{MASQUeRADE}

Weary of angelic beauty, the angel spent its time pulling faces in the mirror. Until it achieved na expression of perfect horror. It then decide to take a stroll on Earth. And Lili, the first little girl to catch sight of the Angel, shouted into the house: "Mummy! Mummy! Come and see how pretty Frankenstein is looking today!" 


\section{As FaLSAS ReCORDAÇÕES}

Se a gente pudesse escolher a infância que teria vivido, com que enternecimento eu não recordaria agora aquele velho tio de perna de pau, que nunca existiu na família, e aquele arroio que nunca passou aos fundos do quintal, e onde íamos pescar e sestear nas tardes de verão, sob o zumbido inquietante dos besouros...

\section{False Memories}

If one could have the childhood of one's choice, with what affection I should remember that old uncle with the wooden leg who never existed in my family, and that stream which never passed at the bottom of our garden, where we used to fish and take our siesta on summer afternoons beneath the unnerving drone of bees...

\section{Carta Desesperada}

Como é difícil, como é difícil, Beatriz, escrever uma carta...

Antes escrever os Lusíadas!

Com uma carta pode acontecer

Que qualquer mentira venha a ser verdade...

Olha! O melhor é que te descrever, simplesmente,

A paisagem,

Descrever sem nenhuma imagem, nenhuma...

Cada coisa é ela própria a sua maravilhosa imagem!

Agora mesmo parou de chover. Não passa ninguém. Apenas

Um gato

Atravessa a rua

Como nos tempos quase imemoriais 
MILTON, John. Giovanni Pontiero: Translations of Mario Quintana

Do cinema silencioso...

Sabes, Beatriz? Eu vou morrer!

\section{Letter Written IN Despair}

How difficult. How difficult, Beatrice, to write a letter...

Much easier to compose the Lusiads!

With a letter it's all too easy

For lies to pass as truths...

Listen! Let me simply describe

The landscape.

A description without images, not even one...

Each thing is its own marvellous image!

The rain has just stopped.

No one is passing. Only

A cat

Crossing the street

As in that almost forgotten age

Of silent films...

Did I tell you, Beatrice? I'm going to die.

\section{DA COR}

Há uma cor que não vem nos dicionários. É essa indefinível cor que têm todos os retratos, os figurinos da última estação, a voz das velhas damas, os primeiros sapatos, certas tabuletas, certas ruazinhas laterais: - a cor do tempo.

\section{Colour}

There's a colour you don't find in dictionaries. It's that indefinable colour all portraits have, last season's fashion models, the voices 
of old ladies, one's first pair of shoes, certain sign boards, certain side-streets: - it's the colour of time...

\section{NOTURNO}

O relógio costura, meticulosamente, quilômetros e quilômetros do silêncio noturno.

De vez em quando, os velhos armários estalam os ossos.

Na ilha do pátio, o cachorro, ladrando.

(é a a lua).

E, à lembrança da lua, Lili arregala os olhos no escuro.

\section{Nocturne}

The clock stitches, meticulously, kilometre upon kilometre of nocturnal silence.

From time to time, the old cupboards creak like bones.

In the island of the courtyard, the dog, barking.

(It's the moon)

And, remembering the moon, Lili opens her eyes wide in the dark. 


\section{Do SOBRenAtUral}

Vozes ciciando nas frinchas... vozes de afogados soluçando nas ondas... vozes noturnas chamando... pancadas no quarto ao lado, por detrás dos móveis, debaixo da cama... gritos de assassinados ecoando ainda nos corredores malditos... Qual nada! $O$ que mais amedontra é o pranto dos recém-nascidos: aí é que está a verdadeira voz do outro mundo.

\section{The SuPERnAtural}

Voices whispering in the crevices... Voices of drowned men sobbing in the waves... nocturnal voices calling... banging in the next room, behind the furniture, underneath the bed... the cries of murdered men still echoing in cursed passageways... No such thing! Most terrifying of all is the weeping of new-born babes: there is the real voice of the other world.

\section{ANÊMONA}

Não é preciso um verso... nem

$$
\text { Uma oração }
$$

Basta que digas a palavra anêmona

E tudo esquecerás, enredado na sua

Fantasmagórica palpitaçāo.

\section{ANEMONE}

No need for verse... or

Prayer... 
Simply say the word anemone

And you will forget everything, entangled in its

Illusive vibrations.

\section{O MORTO}

Eu estava dormindo e me acordaram

E me encontrei, assim num mundo estranho e louco...

E quando eu começava a compreendê-lo

Um pouco,

Já eram horas de dormir de nôvo!

\section{The Dead Man}

I was sleeping and they woke me up

Only to find myself in this strange, mad world...

And no sooner had I begun to understand it

Just a little,

When it was time to sleep again!

\section{Chäo de Outono}

Ao longo das pedras irregulares do calçamento passam ventando umas pobres fôlhas amarelas em pânico, perseguidas de perto por um convite-de-entêrro, sinistro, tatalando, aos pulos, cada vez mais perto, as duas asas tarjadas de negro! 
MILTON, John. Giovanni Pontiero: Translations of Mario Quintana

\section{The Pavement in Autumn}

Along the rough paving stones, withered yellow leaves sweep past in panic, closely pursued by a funeral notice, ominous, rustling, leaping, drawing closer, both sides bordered in black!

\section{Da Paginaçāo}

Os livros de poemas devem ter margens largas e muitas páginas em branco e suficientes claros nas páginas impressas, para que as crianças possam enchê-los de desenhos - gatos, homens, aviōes, casas, chaminés, árvores, luas, pontes, automóveis, cachorros, cavalos, bois, tranças, estrêlas, - que passarão também a fazer parte dos poemas...

\section{Pagination}

Books of verse should have wide margins and lots of blank pages and enough space on the printed ones for children to fill with drawings - cats, men, aeroplanes, houses, chimneys, trees, the moon, bridges, motor-cars, dogs, horses, oxen, puzzles, stars which will also become part of the poem...

\section{TRISTE ÉPOCA}

Em nossa triste época de igualitarismo e vulgaridade, as únicas criaturas que mereceriam entrar numa história de fads são os mestre-cucas, com os seus invejáveis gorros brancos e os porteiros dos grandes hotéis, com os seus alamares, os seus ademanes, a sua indiscutida majestade. 


\section{SAD TIMES}

In these sad times of equality and bad taste, the only creatures worthy of appearing in fairy-tales are master-chefs with their enviable white hats and the doormen of grand hotels with their braided uniforms, their gestures and undisputed majesty.

\section{PINO}

Doze touros

Arrastam a pedra terrivel.

Doze touros.

Os músculos vibram

Como cordas.

Nenhuma rosa

Nos cornos sonoros.

Nenhuma

Nas tôrres que ficam acima das nuvens

Exausto de azul

Boceja o Rei dos Ouros.

\section{ZENITH}

Twelve bulls

Drag the terrible stone.

Twelve bulls.

Their muscles straining

Like ropes. 
No rose

On their sonorous horns.

None.

In the lofty towers above the clouds

Weary of blue

The King of Diamonds yawns.

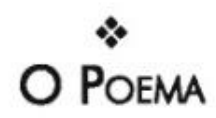

Poema é uma pedra no abismo,

$O$ eco do poema desloca os perfis:

Para bem das águas e das almas

Assassinemos o poeta.

\section{The Poem}

The poem is a stone in the abyss

The poem's echo dislocates outlines:

For the good of waters and souls

Let us assassinate the poet.

\section{A C}

Hoje encontrei dentro de um livro uma velha carta amarelecida, Rasguei-a sem procurar ao menos saber de quem seria...

Eu tenho um mêdo

Horrível

A esses mares montantes do passado, 
Com suas quilhas afundadas, com

Meus sucessivos cadáveres amarrados aos mastros e gáveas...

Ai de mim.

Ai de ti, ó velho mar profundo,

Eu venho sempre à tona de todos os naufrágios!

\section{THE LeTter}

Today I found a letter, the paper faded, inside a book, I tore it up without even trying to discover who sent it... I have a fear, A horrible fear

Of those rising tides from the past, With their sunken keels, with

My successive corpses lashed to the mast and top-sails...

Woe is me,

Woe is you, old, deep sea,

I always surface from every shipwreck!

\section{ElegIa URBana}

Rádios. Tevês.

Go00000000000000000000000000000l!!!

(o domingo é um cachorro escondido debaixo da cama)

\section{URBAN ELEGY}

Radios. Teles.

Go0000000000000000000000000000al!!!

(Sunday is a dog hiding under the bed) 


\begin{abstract}
ALEGRIA
Não essa alegria fácil dos cabritos monteses

Nem a dos piōes regirando

Mas

Uma alegria, a serena alegria que fulge no olhar dos santos

Ante a presença luminosa da morte!
\end{abstract}

\title{
HAPPINESS
}

Not that facile happiness of little mountain goats

Nor that of spinning tops

But

A happiness without rattles or tambourines...

That's the hapiness I have longed for:

The immortal, serene happiness that shines from the eyes of saints

Before the luminous presence of death!

\section{TABLEAU!}

Nunca se deve deixar um defunto sòzinho. Ou, se fizermos, é recomendável tossir discretamente ates de entrar de novo na sala. Uma noite em que eu estava a sós com uma dessas desconcertantes criaturas, acabei aborrecendo-me (pudera!) e fui beber qualquer coisa no bar mais próximo. Pois nem queira saber... Quando voltei, quando entrei inopinadamente na sala, estava êle sentado no caixāo, comendo sôfregamente uma das quatro velas que o ladeavam! E só Deus sabe o constragimento em que nos vimos os dois, os nossos míseros gestos de desculpa e os sorrisos amarelos que trocamos... 


\section{TABleau!}

We should never leave a corpse unattended. Or if we do, it's advisable to cough discreetly before re-entering the room. One night when I found myself alone with one of these disconcerting creatures, I eventually got bored (no wonder!) and went to have a drink in the nearest bar. You wouldn't believe it... When I returned and unexpectedly entered the room, there was the corpse sitting up, avidly devouring one of the four candles round the coffin. God alone knows how embarrassed we felt as our eyes met, miserable gestures of apology and the wan smiles we exchanged...

$$
\stackrel{*}{\text { IF... }}
$$

Até hoje não me esqueci

Do Anjo da Anunciaçāo no quadro de Boticelli:

Como pode alguém

Apresentar-se ao mesmo tempo tão humilde e cheio de tamanha dignidade?

Oh! Tão soberanamente inclinado...

Se pudéssemos ser como ele!

Os Anjos dão tudo de si

Sem jamais se despirem de nada.

$$
\text { IF... }
$$

I shall never forget

The Angel in Boticelli's Annunciation:

How can someone

Appear so humble and dignified at the same time? 
MILTON, John. Giovanni Pontiero: Translations of Mario Quintana

Oh! Bowing with such nobility...

If only we could be like him!

The Angels give all they possess

Without stripping themselves of anything.

\section{VARIAÇĀo SOBRE UM TEMA}

Tenho pena, isto sim, dos que viajam de avião a jacto:

Só conhecem do mundo os aeroportos...

E todos os aeroportos do mundo são iguais, excessivamente sanitários

E com anúncios de Coca-Cola.

\section{VARIATION ON A THEME}

I pity those who travel by jumbo and jet:

They only know the world of airports...

And all airports in the world are the same, excessively hygienic And with advertisements for Coca-Cola. 


\section{O Poeta e a Sereia}

Sereiazinha do rio lbira...

Feiosa,

Até sardas tem.

Cantar não sabe:

Olha e me quer bem.

Seus ombros têm frio.

Embalo-a nos joelhos,

Ensino-lhe catecismo

E conto histórias que inventei especialmente para seu espanto.

Um dia ela voltou para o seu elemento!

Sereiazinha,

Eu é que sinto frio agora...

\section{The Poet and the Mermaid}

Little mermaid from the river lbira...

Unprepossessing,

With her freckled face.

Unable to sing:

She sees me and falls in love.

Her shoulders shivering with cold.

I nurse her on my lap.

I teach her catechism

And tell her stories I've invented specially to impress her.

One day she returned to her natural habitat!

Little mermaid,

Now it's me who's feeling cold. 
MILTON, John. Giovanni Pontiero: Translations of Mario Quintana

\section{Poesia Pura}

Um lampião de esquina

Só pode ser comparado a um lampião de esquina,

De tal maneira ele é ele mesmo

Na sua ardente solidāo!

\section{Pure Poetry}

A street-lamp on the corner

Can only be compared with a street-lamp on the corner,

So true is that lamp to itself

In its ardent solitude.

\section{TERRA}

Terra! Um dia comerás meus olhos...

Eles eram

No entanto

O verde único de tuas folhas

mais puro cristal de tuas fontes...

Meus olhos eram os teus pintores!

Mas, afinal, quem precisa de olhos para sonhar?

A gente sonha é de olhos fechados.

Onde quer que esteja... onde for que seja...

Na mais densa treva eu sonharei contigo,

Minha terra em flor! 


\section{EARTH}

Earth! One day you'll devour my eyes...

Yet

They were

The only green of your leaves

The purest crystal of your fountains...

My eyes were your painters!

But, after all, who needs eyes to dream?

People dream with their eyes closed.

Wherever you decide... wherever it may be...

In darkest night, I'll dream of you

My flowering earth!

\section{O VIAJANTE}

Eu sempre que parti, fiquei nas gares

Olhando, triste, para mim...

\section{The Traveller}

Whenever I departed, I remained in the stations Looking sadly at myself... 
MILTON, John. Giovanni Pontiero: Translations of Mario Quintana

\section{BeM-AVENTURADOS}

Bem-aventurados os pintores escorrendo luz Que se expressam em verde

Azul

Ocre

Cinza

Zarçāo!

Bem-aventurados os músicos...

E os balarinos

E os mímicos

E os matemáticos...

Cada qual na sua expressāo!

Só o poeta é que tem de lidar com a ingrata linguagem alheia...

A impura linguagem dos homens!

\section{The Blessed}

Blessed are the painters filtering light

Who express themselves in green

Blue

Ochre

Grey

Red!

Blessed are the musicians...

The dancers

The mimers

The mathematicians...

Each with his own expression! 
Only the poet struggles with thankless, alien language...

The impure language of men!

\section{DOgma e RITUAL}

Os dogmas assustam como trovōes

E que medo de erra a sequência dos ritos!

Em compensação,

Deus é mais simples do que as religiões.

\section{DOgma AND RItUAl}

Dogmas terrify like claps of thunder

And such dread of confusing the sequence of rites!

In recompense,

God is much simpler than any religion.

\section{$\stackrel{*}{\text { SEMPRE }}$}

Sou o dono dos tesouros perdidos o fundo do mar.

Só o que está perdido é nosso para sempre.

Nós só amamos os amigos mortos

E só amadas mortas amam eternamente...

\section{FOREVER}

I am master of the lost treasures at the bottom of the sea.

Only what is lost is ours forever.

We only love friends who are dead

And only dead mistresses love eternally... 
MILTON, John. Giovanni Ponfiero: Translations of Mario Quintana

\section{$\mathrm{H}_{\mathrm{AI}}-\mathrm{K}_{\mathrm{AI}}$}

Rosa suntuosa e simples,

Como podes estar tão vestida

E ao mesmo tempo inteiramente nua?

\section{$\mathrm{HAl}_{\mathrm{Al}} \mathrm{K}_{\mathrm{Al}}$}

Sumptuous and simple rose clothed to perfection yet stark naked?

\section{BIOGRAFIA}

Entre o olhar suspeitoso da tia E o olhar confiante do cão

O menino inventava a poesia...

\section{BIOGRAPHY}

Betwen his aunts suspicious look And the dog's trusting gaze The little boy invented poetry...

\section{Dois Versos para Greta Garbo}

O teu sorriso é imemorial como as Pirâmides e puro como a flor que abriu na manhã de hoje... 


\section{Two lines for Greta Garbo}

Your smile is as immemorial as the Pyramids and as pure as the flower that opened at dawn...

\section{Terceiro Poema de Muito Longo}

Da última vez que atravessei aquele corredor escuro, Ele estava cheio de passarinhos mortos.

\section{Third Poem from Afar}

The last time I crossed that dark corridor, It was full of tiny dead birds.

\section{OS PRISIONEIROS}

Os muros móveis do vento

Compōem minha casa-barco.

Quem foi que me prendeu por dentro

De uma gota dágua?

Tolice matar-se a gente

Só por isso...

Nem ele mesmo, o Grande Mágico,

Quebra o seu próprio feitiço! 
MILTON, John. Giovanni Pontiero: Translations of Mario Quintana

\section{PRISONERS}

The wind's restless walls

From my floating home.

Who has trapped me inside

$$
\text { A drop of water? }
$$

Foolish to kill oneself

Just for this...

Not even the Great Magician himself,

Breaks his own spell!

\section{INTERROGAÇÕES}

Nenhuma pergunta demanda resposta.

Cada verso é uma pergunta do poeta.

$\mathrm{E}$ as estrelas...

as flores...

o mundo...

são perguntas de Deus.

\section{INTERROGATIONS}

No question demands an answer.

Each verse is a question from the poet.

And the stars...

the flowers...

the world...

are questions from God. 


\section{"A VIDA E UM SONHO"}

$A$ vida? Pode ser que seja um sonho. A poesia não. $A$ "possessão poética" não tem sentido passivo. É o mesmo que no palco: um ator, para bem desempenhar o papel de ébrio, deve estar inteiramente sóbrio.

\section{"Life is a Dream"}

Life? It could be a dream. But not poetry. The "possession of poetry" has no passive meaning. It's the same on the stage: the actor who wants to give a good performance as a drunkard must be completely sober.

\section{TRECHO DE DIÁRIO}

Hoje me acordei pensando em um pedra numa rua de Calcutá. Numa determinada pedra em certa rua de Calcutá.

Solta. Sozinha. Quem repara nela?

Só eu, que nunca fui lá.

Só eu, deste lado do mundo, te mando agora esse pensamento...

Minha pedra de Calcutá!

\section{DIARY ENTRY}

Today I woke up thinking about a tone on a street in Calculta. About a particular stone on a certain street in Calcutta.

Loose. Solitary. Who notices it? 
MILTON, John. Giovanni Pontiero: Translations of Mario Quintana

Only me, who has never been there.

Only me, who from this side of the world, now sends you this thought...

My stone of Calcutta!

\section{No PRINCÍPIO}

No princípio, era a Poesia. No cérebro do homem, só havia imagens... Depois vieram os pensamentos... E por fim, a Filosofia, que é, em última análise, a triste arte de ficar do lado de fora das coisas.

\section{IN THE BeGINNING}

In the beginning there was Poetry. There were only images in the human mind... Then came thoughts... And finally Philosophy which is, after all, the dismal art of remaining outside things. 